This item was submitted to Loughborough's Research Repository by the author.

Items in Figshare are protected by copyright, with all rights reserved, unless otherwise indicated.

\title{
Interface study by dual-beam FIB-TEM in a pressureless infiltrated $\mathrm{Al}(\mathrm{Mg})$ -
} Al2O3 interpenetrating composite

PLEASE CITE THE PUBLISHED VERSION

PUBLISHER

(C) Blackwell Publishing

VERSION

AM (Accepted Manuscript)

LICENCE

CC BY-NC-ND 4.0

\section{REPOSITORY RECORD}

Chan, H., Rebecca L. Higginson, and J.G.P. Binner. 2009. "Interface Study by Dual-beam FIB-TEM in a Pressureless Infiltrated Al(mg)-al2o3 Interpenetrating Composite”. figshare. https://hdl.handle.net/2134/4174. 
This item was submitted to Loughborough's Institutional Repository (https://dspace.lboro.ac.uk/) by the author and is made available under the following Creative Commons Licence conditions.

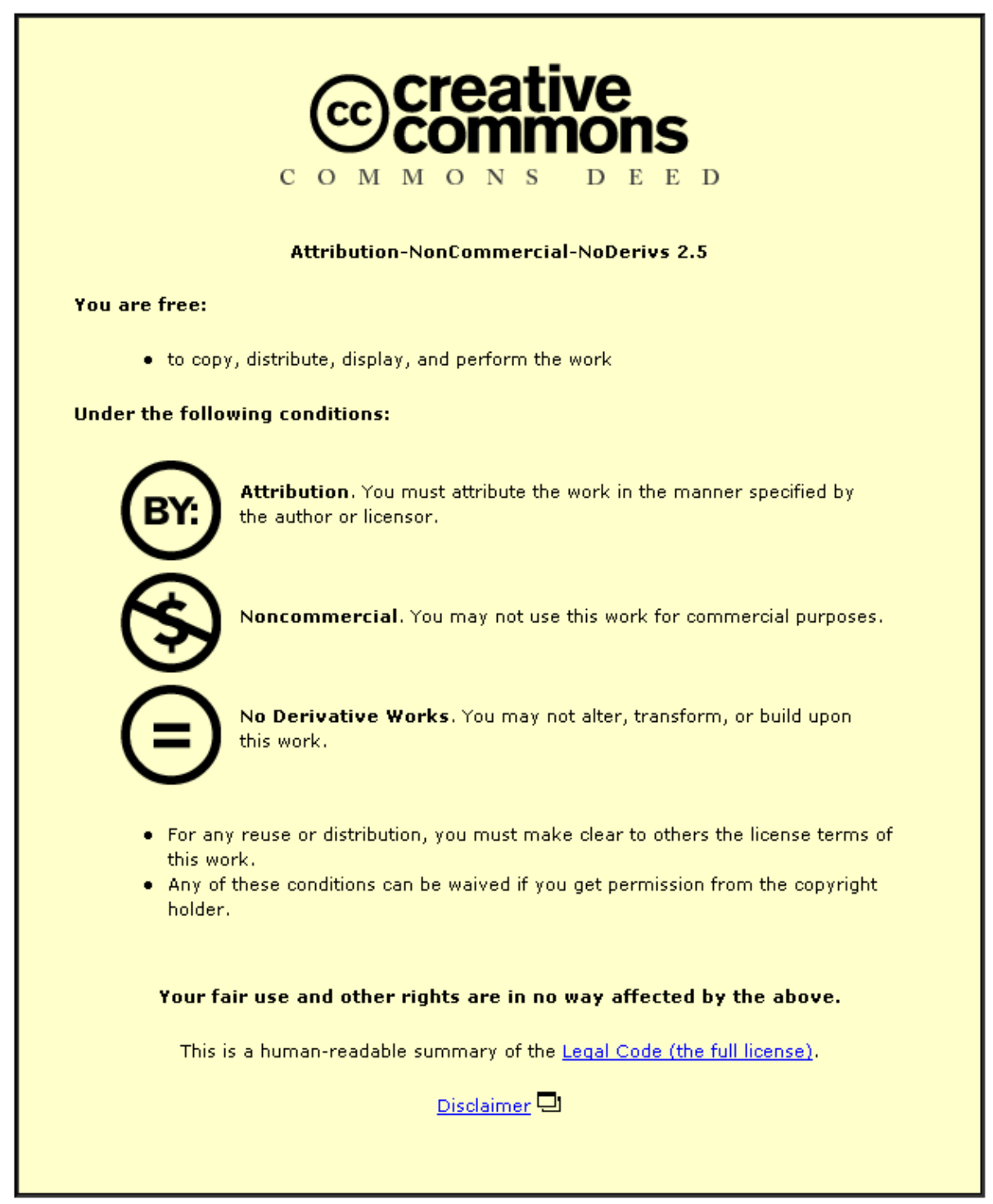

For the full text of this licence, please go to: http://creativecommons.org/licenses/by-nc-nd/2.5/ 


\title{
Interface Study by Dual Beam FIB-TEM in a pressureless infiltrated
}

\section{$\mathrm{Al}(\mathrm{Mg}) / \mathrm{Al}_{2} \mathrm{O}_{3}$ Interpenetrating Composite}

\author{
H. Chang*, R. L. Higginson \& J. G. P. Binner \\ IPTME, Loughborough University, Loughborough, LE11 3TU, UK \\ ${ }^{*}$ Corresponding author. E-mail: H.chang@lboro.ac.uk \\ Tel: + 44 (0) 1509263171 4361; Fax: +44 (0) 1509223949
}

\section{Abstract}

This paper considers the microstructures of an $\mathrm{Al}(\mathrm{Mg}) / \mathrm{Al}_{2} \mathrm{O}_{3}$ interpenetrating composite produced by a pressureless infiltration technique. It is well known that the governing principle in pressureless infiltration in $\mathrm{Al} / \mathrm{Al}_{2} \mathrm{O}_{3}$ system is the wettability between the molten metal and the ceramic phase; however, the infiltration mechanism is still not well understood. The objective of this research was to observe the metal / ceramic interface to understand the infiltration mechanism better. The composite was produced using an Al-8wt.\% Mg alloy and $15 \%$ dense alumina foams at $915^{\circ} \mathrm{C}$ in a flowing $\mathrm{N}_{2}$ atmosphere. After infiltration, the composite was characterized by a series of techniques. Thin film samples, specifically produced across the $\mathrm{Al}(\mathrm{Mg})-\mathrm{Al}_{2} \mathrm{O}_{3}$ interface, were prepared using a Dual Beam Focused Ion Beam (FIB) and subsequently observed using Transmission Electron Microscopy (TEM). XRD scan analysis shows that $\mathrm{Mg}_{3} \mathrm{~N}_{2}$ formed in the foam at the molten alloy-ceramic infiltration front whilst TEM analysis revealed that fine AIN grains formed at the metal / ceramic interface and $\mathrm{MgAl}_{2} \mathrm{O}_{4}$ and $\mathrm{MgSi}_{2}$ grains formed at specific points. It is concluded that it is the reactions 
between the $\mathrm{Al}, \mathrm{Mg}$ and $\mathrm{N}_{2}$ atmosphere that improve the wettability between molten $\mathrm{Al}$ and $\mathrm{Al}_{2} \mathrm{O}_{3}$ and induce spontaneous infiltration.

\section{Introduction}

Aluminium alloys reinforced with ceramic particles or fibres are desired composites in high performance applications due to their superior properties; light weight combined with high modulus, strength, hardness and wear resistance; good thermal conductivity and reduced coefficient of thermal expansion. Compared with traditional particulate or fibre reinforced composites, 3-3 interpenetrating composites with both matrix and reinforcement co-continuous throughout the microstructure are more attractive in providing superior application-tailored multifunctional and novel properties (Clarke, 1992). The pressureless infiltration of molten metals into ceramic foams (Binner et al., in press) is potentially superior to more traditional methods such as squeeze casting, having the advantages of there being no requirement for high pressure and hence offering potentially low cost and near net shape production. However, due to the poor wettability between molten aluminium and ceramics, pressureless infiltration requires the presence of both $\mathrm{Mg}$ and a nitrogenous infiltration atmosphere (Aghjanian et al., 1991). Although it is widely accepted that $\mathrm{Mg}$ is a strong surfactant and it improves the wettability of molten $\mathrm{Al}$ with $\mathrm{Al}_{2} \mathrm{O}_{3}$ (Zhong et al., 1989), the infiltration mechanism is still not completely understood.

Rao and Jayaram (Rao \& Jayaram, 2001) investigated the pressureless infiltration of $\mathrm{Al}-\mathrm{Mg}$-based alloys into alumina preforms and concluded that the role of $\mathrm{Mg}$ was 
two fold, namely, in initiating, and then continuing, infiltration. Initiation was caused by the reaction(s) of $\mathrm{Mg}$ with the surface $\mathrm{Al}_{2} \mathrm{O}_{3}$ to form a non-protective oxide layer, which eroded the passivating $\mathrm{Al}_{2} \mathrm{O}_{3}$ layer and brought about the contact between the molten metal and the ceramic preform. The continuation of the infiltration was caused by the Mg gathering oxygen, therefore keeping the front free of passivating alumina, whilst termination was due to localised $\mathrm{Mg}$ depletion at the infiltration front. The Mg loss might have resulted from $\mathrm{Mg}$ evaporation or the formation of $\mathrm{MgO}$ and $\mathrm{MgAl}_{2} \mathrm{O}_{4}$. However, from a study of the role of $\mathrm{Mg}$ and $\mathrm{N}_{2}$ during the spontaneous infiltration of aluminium eutectic alloys into partially nitrided AA6061 aluminium powder preforms, Sercombe and Schaffer (Sercombe \& Schaffer, 2004) concluded that the formation of AIN was critical for the infiltration; Mg was beneficial, but not sufficient. They concluded that AIN improved the wettability and facilitated spontaneous infiltration; whereas $\mathrm{Mg}$ was helpful in scavenging the oxygen and, as a result, creating a microclimate with extremely low oxygen partial pressure that facilitated the formation of the AIN. Saravanan et al. (Saravanan et al., 2001) studied the effect of $\mathrm{N}_{2}$ on Al surface tension and reported that $\mathrm{N}_{2}$ greatly reduced it well below the values found in an Ar atmosphere at temperatures higher than $850^{\circ} \mathrm{C}$ as a result of the formation of AIN.

Based on the fact that both $\mathrm{Mg}$ and $\mathrm{N}_{2}$ are needed for the pressureless infiltration, another assumption is that the spontaneous infiltration is dependent on the reaction between $\mathrm{Mg}$ and $\mathrm{N}_{2}$ to form $\mathrm{Mg}_{3} \mathrm{~N}_{2}$ (Lee et al., 1998):

$$
3 M g+N_{2} \rightarrow M_{3} N_{2}
$$

This then reacts with $\mathrm{Al}$ to form AIN:

$$
M g_{3} N_{2}+2 \mathrm{Al} \rightarrow 2 \mathrm{AlN}+3 \mathrm{Mg}
$$


It is believed that reaction (2) is important in improving wetting and aids infiltration (Schiroky et al., 1997), the overall reaction being:

$$
A l+N_{2} \rightarrow A l N
$$

$\mathrm{Mg}$ is retained in the cycle and reintroduced to the melt, which acts as a catalyst (Hou et al., 1995).

This research considers the microstructures formed in $\mathrm{Al}(\mathrm{Mg}) / \mathrm{Al}_{2} \mathrm{O}_{3}$ interpenetrating composites produced using the pressureless infiltration technique. The fine-scale microstructure at the $\mathrm{Al}-\mathrm{Al}_{2} \mathrm{O}_{3}$ interface was observed using TEM. Schematics of the infiltration, the interfacial development processes and the reactions that might assist the infiltration are discussed.

\section{Experimental}

Alumina foams, with a density of $15 \mathrm{wt} . \%$ and an average cell diameter of $60 \mu \mathrm{m}$, were manufactured by Dytech Corp. Ltd, UK, using a gel-casting technique (Sepulveda \& Binner, 1999). The metal infiltrant, an Al-8Mg alloy, was prepared from commercially pure $\mathrm{Al}$ and an Mg-Al master alloy AZ81 using an approach described elsewhere (Binner et al., in press).

To fabricate the composites, discs of alumina foams measuring $50 \times 20 \times 9 \mathrm{~mm}$ were placed on top of an Al-8Mg alloy disc of the same size, the foam/alloy couples being held in alumina boats ${ }^{1}$. The arrangement was then heated at $20^{\circ} \mathrm{C}$ $\min ^{-1}$ in a tube furnace in an argon atmosphere; to avoid temperature overshoot,

\footnotetext{
${ }^{1}$ Note: It made no difference whether the ceramic foams were placed on top of the alloy discs or vice versa.
} 
the heating rate was reduced to $5^{\circ} \mathrm{C} \min ^{-1}$ from $850^{\circ} \mathrm{C}-915^{\circ} \mathrm{C}$. Once the temperature reached $915^{\circ} \mathrm{C}$, the argon atmosphere was switched to flowing pure nitrogen. A holding time of 20 mins at $915^{\circ} \mathrm{C}$ was used in order to obtain complete infiltration. To minimise metal shrinkage porosity, the composites were cooled at 15 $-20^{\circ} \mathrm{C} \min ^{-1}$ in flowing argon to $680^{\circ} \mathrm{C}$, followed by furnace cooling in static argon at $5-10^{\circ} \mathrm{C} \min ^{-1}$ to room temperature. Partially infiltrated samples were obtained by holding the metal-ceramic couple at $915^{\circ} \mathrm{C}$ in $\mathrm{N}_{2}$ for 10 mins followed by the same cooling process in $\mathrm{N}_{2}$.

Following production, the composites were cut longitudely then ground and polished metallographically using diamond paste with a final polishing using 0.02 $\mu \mathrm{m}$ colloidal silica. The density of the composites was measured based on the Archimedean principle using a hydrostatic balance with a resolution of $0.1 \mathrm{~g} \mathrm{~cm}^{-3}$. At least 3 measurements were performed on each sample. The microstructures of the alumina foams and the composites were examined using a LEO VP 1530 FEG SEM. XRD analysis was performed on the polished composite samples, the partially infiltrated foam and, for comparison, the un-infiltrated alumina foam. Small polished samples were used for the preparation of TEM samples in a Dual Beam Nanolab 600 FEI FIB. The samples were approximately $20 \times 5 \times 0.2 \mu \mathrm{m}$ in size and produced across the alloy- $\mathrm{Al}_{2} \mathrm{O}_{3}$ interface. The foils were examined in a JEOL JEM 2000FX TEM and in a FEI F20 Tecnai field emission TEM/STEM system (EDS resolution 2 - $3 \mathrm{~nm}$ ) for elemental analysis. 


\section{Results}

Micrographs of the alumina foam and the infiltrated composite are shown in Fig. 1. From Fig. 1 (a), it can be seen that the foam had interconnected porosity in the form of approximately spherical cells connected by circular windows, a typical microstructure for the foams prepared using the gel-casting technique. Fig. 1 (b) and (c) show that the foam was completely infiltrated by the molten metal; the brighter phase is $\mathrm{Al}$ and the darker, $\mathrm{Al}_{2} \mathrm{O}_{3}$. The density measurements showed that the composites were between $98-99 \%$ of theoretical; the $\sim 1 \%$ porosity being due to closed pores in the foam struts and / or metal shrinkage. From Fig. 1(c), good metal-ceramic bonding was seen and no bulk second phase was observed in the composite. Fracture surface observation of the composites after 3-point bending measurements showed good metal-ceramic interfacial bonding with cracks preferentially propagated through the ceramic phase. Data on the mechanical performance of the composites is being published elsewhere (Reference).

XRD scans of the infiltrated composite, Fig. 2, show that the composite consisted of $\alpha-\mathrm{Al}_{2} \mathrm{O}_{3}$ and $\mathrm{Al}$ alloy. Due to the solid solution of $\mathrm{Mg}$ in $\mathrm{Al}$, the $\mathrm{Al}$ peaks are slightly displaced, $0.3-0.8^{\circ}, 2 \theta$. The intensity of the $\mathrm{Al}_{2} \mathrm{O}_{3}$ peaks in the composite is comparatively much weaker than in the uninfiltrated ceramic foam. A strong peak representing the Al (111) plane, Fig. 2, was observed, which might indicate a preferred orientation in the composites.

Yellow-greenish compounds, believed to be $\mathrm{Mg}_{3} \mathrm{~N}_{2}$ (Hou et al., 1995), were observed on the partially infiltrated foams at the molten alloy-ceramic infiltration 
front. XRD scans of this region support this view, Fig. 3, suggesting a chemical reaction between $\mathrm{Mg}$ and $\mathrm{N}_{2}$ occurred during the infiltration process.

A typical TEM micrograph of the metal-ceramic interface is shown in Fig. 4 (a). No porosity was observed, which indicates good interfacial bonding. An EDS line-scan across the interface (Fig. 4 (b)) shows an increase in both Mg and $\mathrm{N}$ concentration; the line-scan position is shown in the micrograph. This interface layer could be categorized as one thin $\mathrm{Al}-\mathrm{O}-\mathrm{Mg}$ region near the ceramic and a continuous $\mathrm{Al}-\mathrm{N}-\mathrm{O}-$ Mg region near the Al. EDS line-scans across other infiltrated cells were performed and the same results obtained.

To further identify the interface compounds, diffraction patterns were taken. Fig. 5 shows an $\mathrm{Al}_{-} \mathrm{Al}_{2} \mathrm{O}_{3}$ interface, which was approximately $100 \mathrm{~nm}$ thick, together with a diffraction pattern from the $\mathrm{Al}-\mathrm{N}-\mathrm{Mg}-\mathrm{O}$ layer (indicated by the arrow). Both AIN and $\mathrm{Al}_{2} \mathrm{O}_{3}$ were identified, although the latter might have been influenced by the $\mathrm{Al}_{2} \mathrm{O}_{3}$ foam. The AIN has a hexagonal structure and, from the figure, is fine grained and forms a continuous layer at the interface. The same analysis was performed on different TEM samples, another example is shown in Fig. 6, where AIN was again identified and observed to be continuous at the $\mathrm{Al}-\mathrm{Al}_{2} \mathrm{O}_{3}$ interface. Although no AIN was detected by XRD, Fig. 2, this is probably a result of the small amount of the AIN formed at the metal-ceramic interface, making it difficult to detect by bulk $\underline{\text { XRD analysis. In contrast, when the composites were produced in a pure nitrogen }}$ atmosphere, AIN was detected by XRD due to the larger quantity formed [Binner et al., in press]. 
$\mathrm{MgAl}_{2} \mathrm{O}_{4}$ was also detected at selective points in the $\mathrm{Al}-\mathrm{O}-\mathrm{Mg}$ region of the $\mathrm{Al}-\mathrm{Al}_{2} \mathrm{O}_{3}$ interface. Fig. 7 (a) shows a spinel formed in this region with a face-centred cubic (FCC) structure. In addition, spinel was also observed inside of the $\mathrm{Al}_{2} \mathrm{O}_{3}$ foam strut; Fig. 7 (b) shows a spinel with a typical angular shape formed on the $\mathrm{Al}_{2} \mathrm{O}_{3}$ grain boundaries.

Fig. 8 shows another TEM micrograph of the alloy-ceramic interface in the composite. Interestingly, as well as the $\mathrm{Al}, \mathrm{Mg}, \mathrm{O}$ and $\mathrm{N}$ layer observed elsewhere, two $\mathrm{Mg}_{2} \mathrm{Si}$ grains were also observed within the alloy matrix, close to the alloyceramic interface. This was the only example of $\mathrm{Mg}_{2} \mathrm{Si}$ that was observed; the formation could be a result of a trace of Si being present in the master alloy, AZ81.

\section{Discussion}

It is well known that for pressureless infiltration, both $\mathrm{Mg}$ and $\mathrm{N}_{2}$ are required; previous results showed that no infiltration occurred at the same temperature using an $\mathrm{Ar}$ atmosphere or without $\mathrm{Mg}$ in the alloy (Binner et al., in press). In this research, $\mathrm{Mg}_{3} \mathrm{~N}_{2}$ has been observed at the infiltration front (Fig. 3), whilst both $\mathrm{Mg}$ and $\mathrm{N}$ elements and a continuous $\mathrm{AIN}$ layer formed at the alloy- $\mathrm{Al}_{2} \mathrm{O}_{3}$ interface (Figs. 4 to 6). This demonstrates that chemical reactions, particularly, nitridation has happened in the system.

Based on the results, schematics of possible infiltration and interface development processes are presented in Fig. 9 . At $915^{\circ} \mathrm{C}$, the atmosphere between the molten $\mathrm{Al}(\mathrm{Mg})$ alloy and $\mathrm{Al}_{2} \mathrm{O}_{3}$ will have consisted of $\mathrm{N}_{2}$ and evaporated $\mathrm{Mg}$ from the 
molten Al alloy (Fig. 9 (a)). The Mg vapour can be expected to react with the $\mathrm{N}_{2}$ to form $\mathrm{Mg}_{3} \mathrm{~N}_{2}$ (reaction (1); $\Delta \mathrm{G}_{915^{\circ} \mathrm{C}}=-213 \mathrm{~kJ} \mathrm{~mol}^{-1}$ (Hou et al., 1995)), which may then deposit onto the surface of the $\mathrm{Al}_{2} \mathrm{O}_{3}$ foam. A possible interfacial morphology at this stage is shown in Fig. 9 (b). $\mathrm{Mg}_{3} \mathrm{~N}_{2}$, however, when contacting molten $\mathrm{Al}$, reacts with the Al to form AIN (reaction (2); $\Delta \mathrm{G}_{915^{\circ} \mathrm{C}}=-175 \mathrm{~kJ} \mathrm{~mol}^{-1}$ (Hou et al., 1995)). It is believed that it is this reaction that induces wetting and pressureless infiltration of molten Al into the ceramic foams (Schiroky et al., 1997). At the same time, $\mathrm{Mg}$ is recycled in this reaction and it can dissolve into the molten metal and/or evaporate again.

The $\mathrm{Mg}$ vapour and/or the $\mathrm{Mg}_{3} \mathrm{~N}_{2}$ may have reacted with the alumina foam to form Al-Mg-O spinel. In addition, $\mathrm{Mg}$ at the $\mathrm{Al}-\mathrm{Al}_{2} \mathrm{O}_{3}$ interface of the infiltrated cells may diffuse along the $\mathrm{Al}_{2} \mathrm{O}_{3}$ grain boundaries towards the $\mathrm{Al}_{2} \mathrm{O}_{3}$ struts as well. One possible reaction is (Pai et al., 1995):

$$
\begin{gathered}
3 \mathrm{Mg}+4 \mathrm{Al}_{2} \mathrm{O}_{3} \rightarrow 3 \mathrm{MgAl}_{2} \mathrm{O}_{4}+2 \mathrm{Al} \\
\Delta \mathrm{G}_{1000^{\circ} \mathrm{C}}=-96.17 \mathrm{~kJ} \mathrm{~mol}^{-1} \text { (Barin, 1989) }
\end{gathered}
$$

where, in addition to spinel, $\mathrm{Al}$ is formed. A schematic of the interface microstructure, after AIN and spinel formation, is shown in Fig. 9 (c). To verify the presence of $\mathrm{Mg}$ in the foam, EDS maps of the $\mathrm{Al}_{2} \mathrm{O}_{3}$ strut in the composite were performed. The results (Fig. 10) show that $\mathrm{Mg}$ is present on the $\mathrm{Al}_{2} \mathrm{O}_{3}$ grain boundaries (Fig. 10 (b)), a result consistent with that in Fig. 7(b). 
Hence, $\mathrm{Mg}_{3} \mathrm{~N}_{2}$ is important in the aspect that it forms and disperses on the surfaces of the $\mathrm{Al}_{2} \mathrm{O}_{3}$ grains, which when contacting molten $\mathrm{Al}$, reacts with the $\mathrm{Al}$ and drives the $\mathrm{Al}$ into the ceramic cells (pores). Besides the nitridation, diffusion of $\mathrm{Mg}$ at the alloy-ceramic interface and the localised formation of spinel may also be beneficial to infiltration in terms of reducing interfacial energy and improving wettability. It should also be noted that reaction of $\mathrm{Mg}$ with residual $\mathrm{O}_{2}$, if there is any in the system, is important in gettering residual oxygen, preventing oxidation and facilitating nitridation (Sercombe \& Schaffer, 2004). Finally, a continuous AIN interfacial layer has formed in the composite at the alloy- $\mathrm{Al}_{2} \mathrm{O}_{3}$ interface, which is important in obtaining good interfacial bonding and properties.

\section{Conclusions}

$\mathrm{Al}(\mathrm{Mg}) / \mathrm{Al}_{2} \mathrm{O}_{3}$ interpenetrating composites have been fabricated by pressureless infiltration in a $\mathrm{N}_{2}$ atmosphere of $\mathrm{Al}-\mathrm{Mg}$ alloy into gel-cast $\mathrm{Al}_{2} \mathrm{O}_{3}$ foams. Good metalceramic interface bonding has been observed in the composites. XRD analysis reveals that the composites contain only $\alpha-\mathrm{Al}_{2} \mathrm{O}_{3}$ and $\mathrm{Al}$, whilst $\mathrm{Mg}_{3} \mathrm{~N}_{2}$ has been observed at the molten alloy-ceramic infiltration front. TEM analysis at the alloyceramic interface reveals that fine $\mathrm{AIN}, \mathrm{MgAl}_{2} \mathrm{O}_{4}$ and $\mathrm{Mg}_{2} \mathrm{Si}$ grains have formed. The results indicate that the infiltration is a capillary action, which is a result of improved wettability between the molten metal and the ceramic by complex chemical reactions. 


\section{Acknowledgement}

The authors would like to thank EPSRC for the financial support and Dytech Corp. Ltd., UK, for supply of the ceramic foams. One of the authors $(\mathrm{H}$. Chang) would like to thank the ORSAS Committee, UK, for financial support. Thanks are also extended to Mr. John Bates and Dr. Geoff West for their help in FIB and TEM operations. 

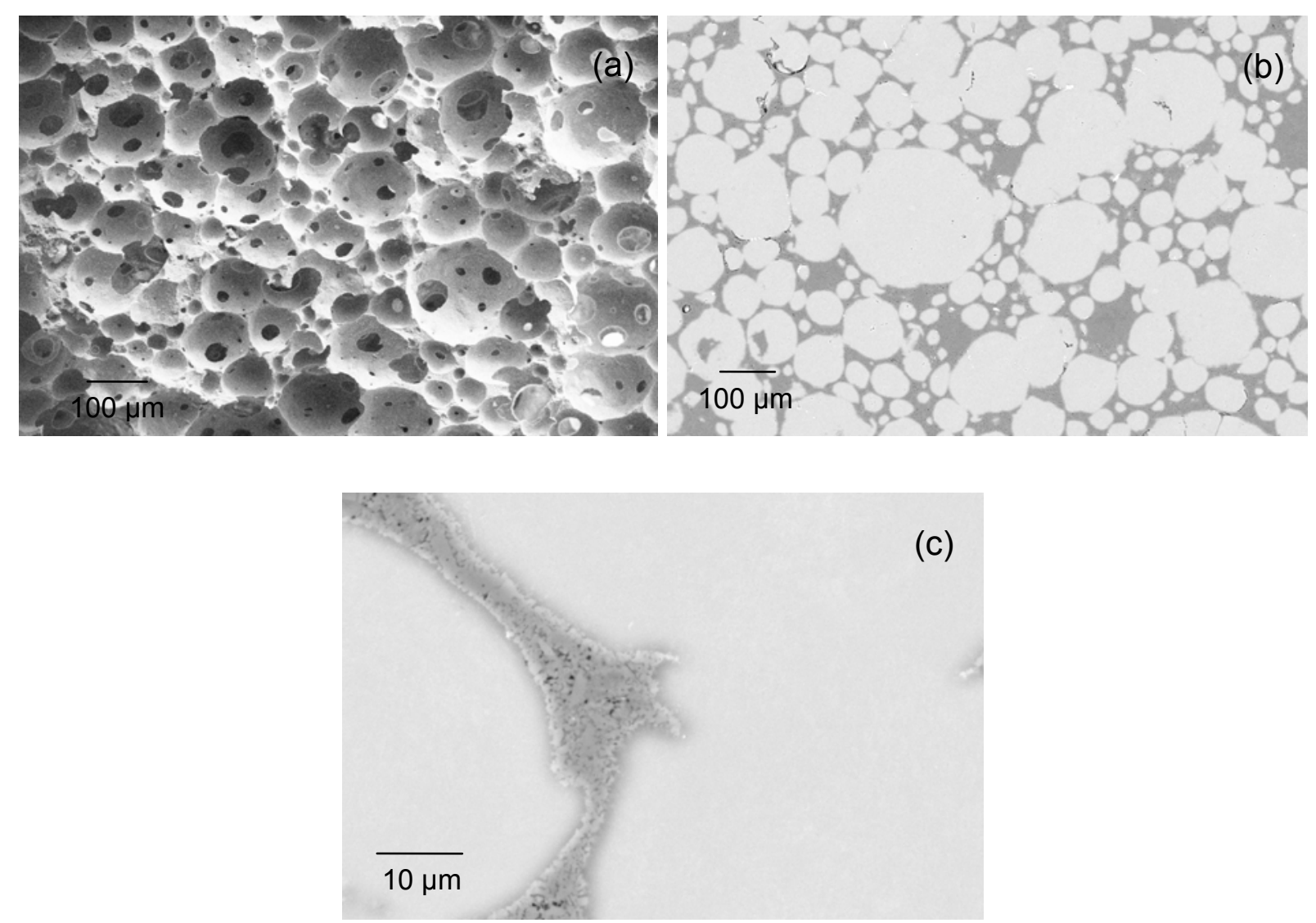

Fig. 1 SEM micrographs of (a) the original alumina foam and $(b, c)$ the composites.

The composite images were taken using the back-scattered mode.

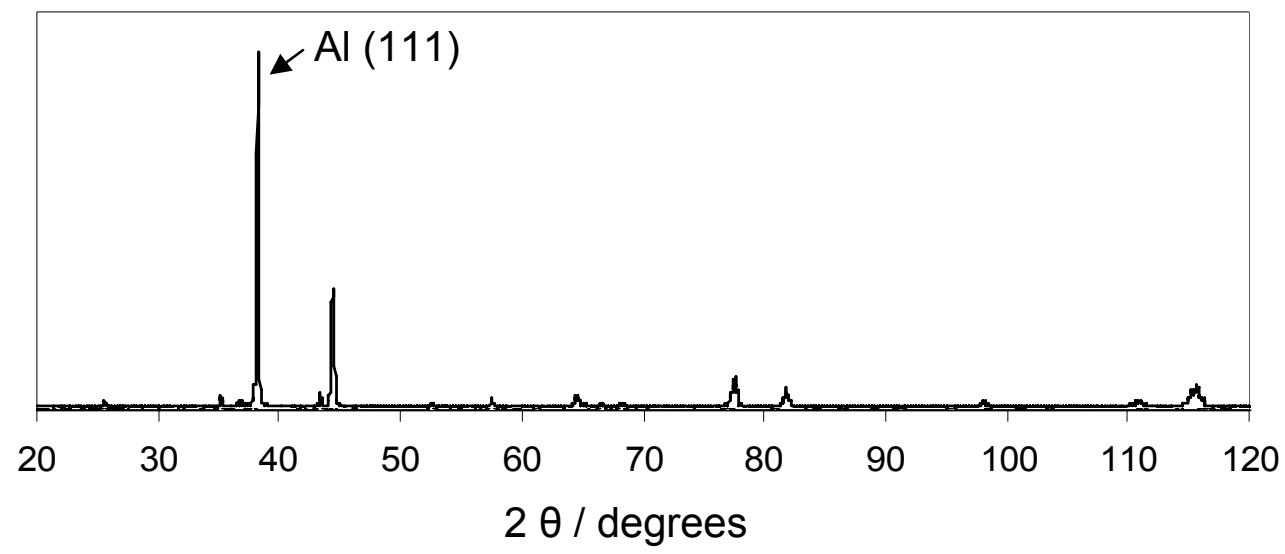

Fig. 2 XRD patterns of the $\mathrm{Al}-8 \mathrm{Mg} / \mathrm{Al}_{2} \mathrm{O}_{3}$ composite. 


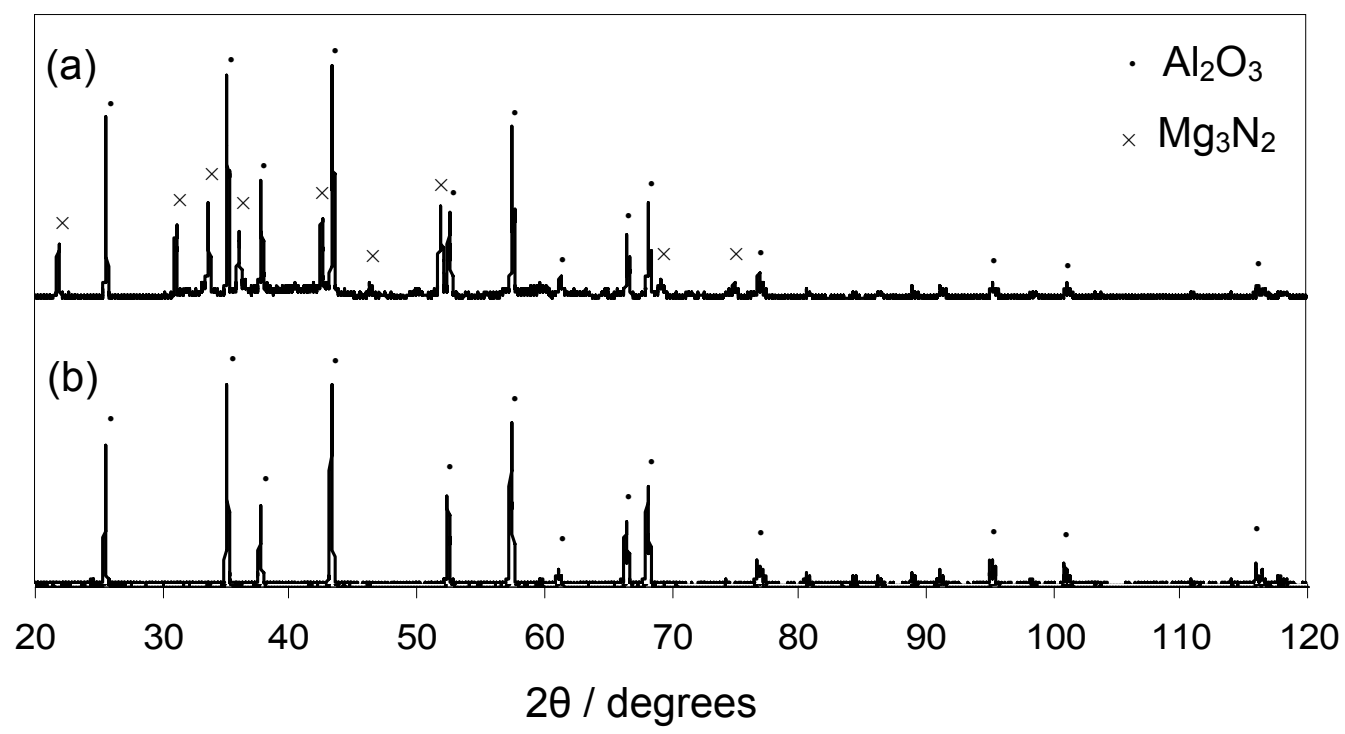

Fig. 3 X-ray analysis of (a) the alumina foam with the yellow-greenish compounds;

(b) the original foam, for comparison.
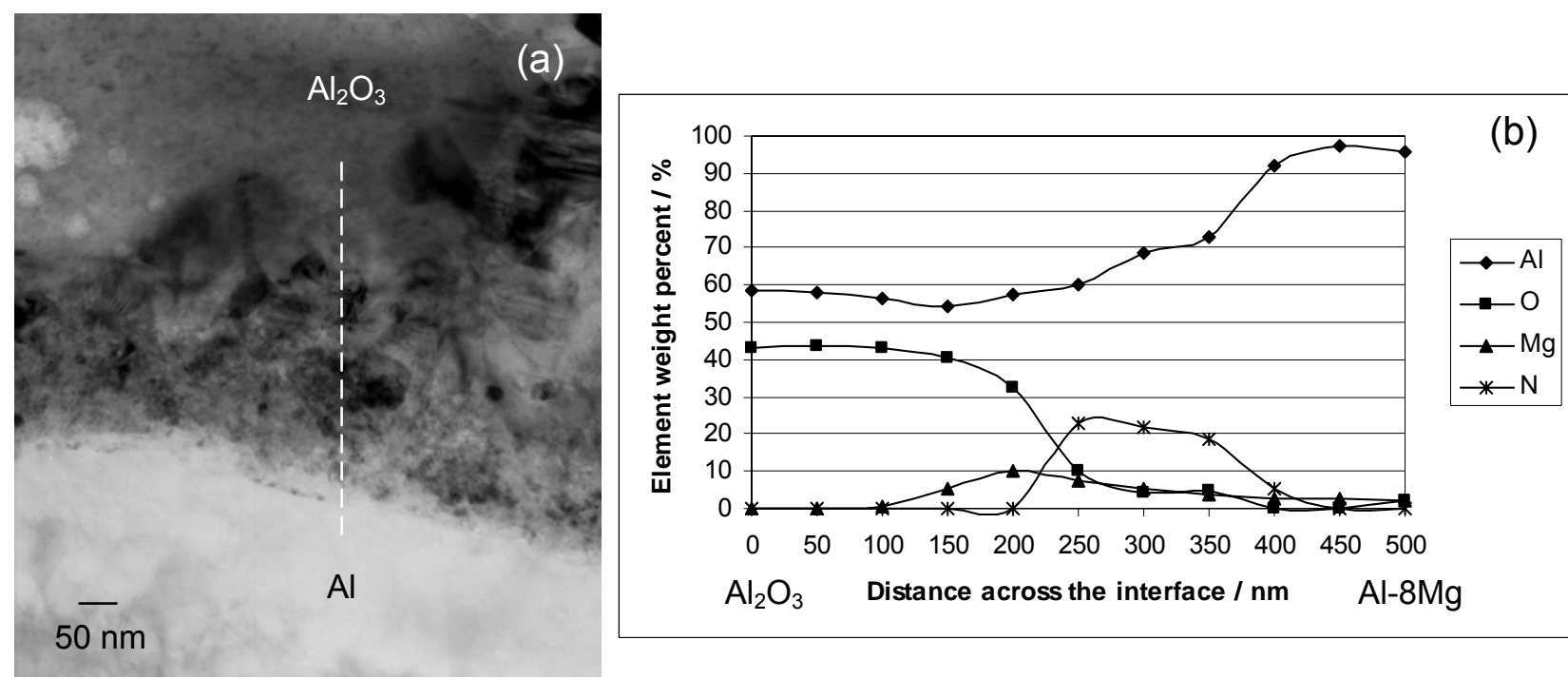

Fig. 4 Composite TEM micrograph at the metal-ceramic interface (a) and the TEMEDS line analysis result across the interface (b). 


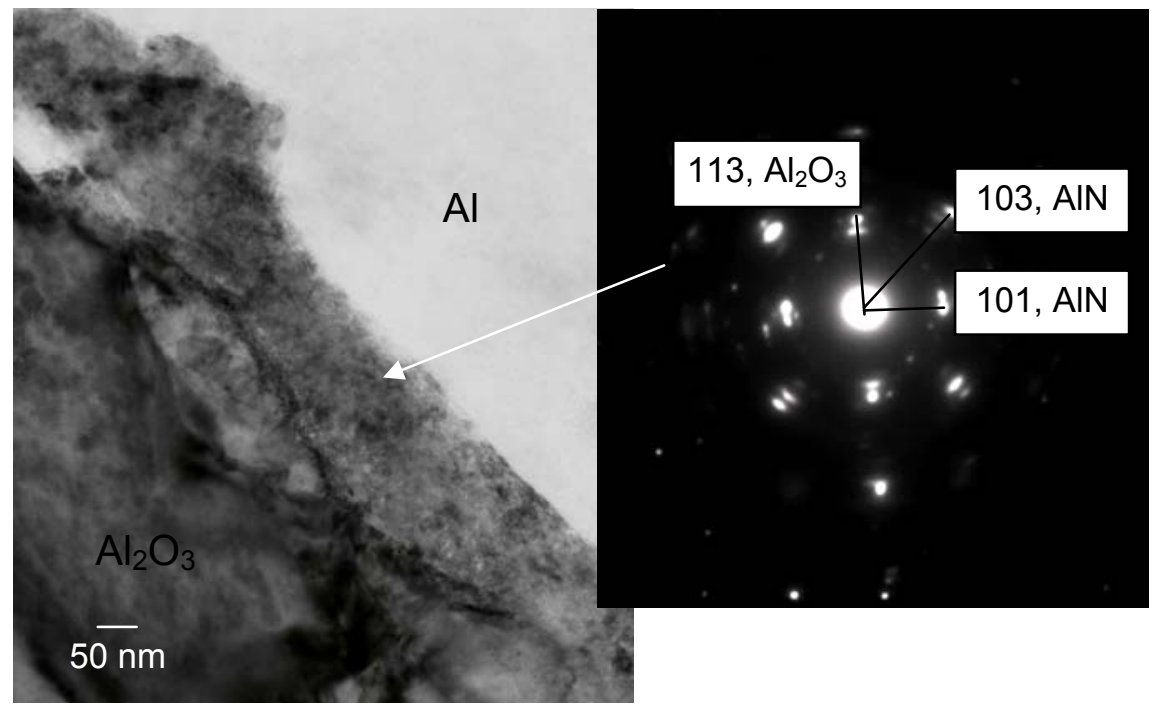

Fig. 5 TEM micrograph and the diffraction pattern of the AIN formed at the metalceramic interface in the composite.

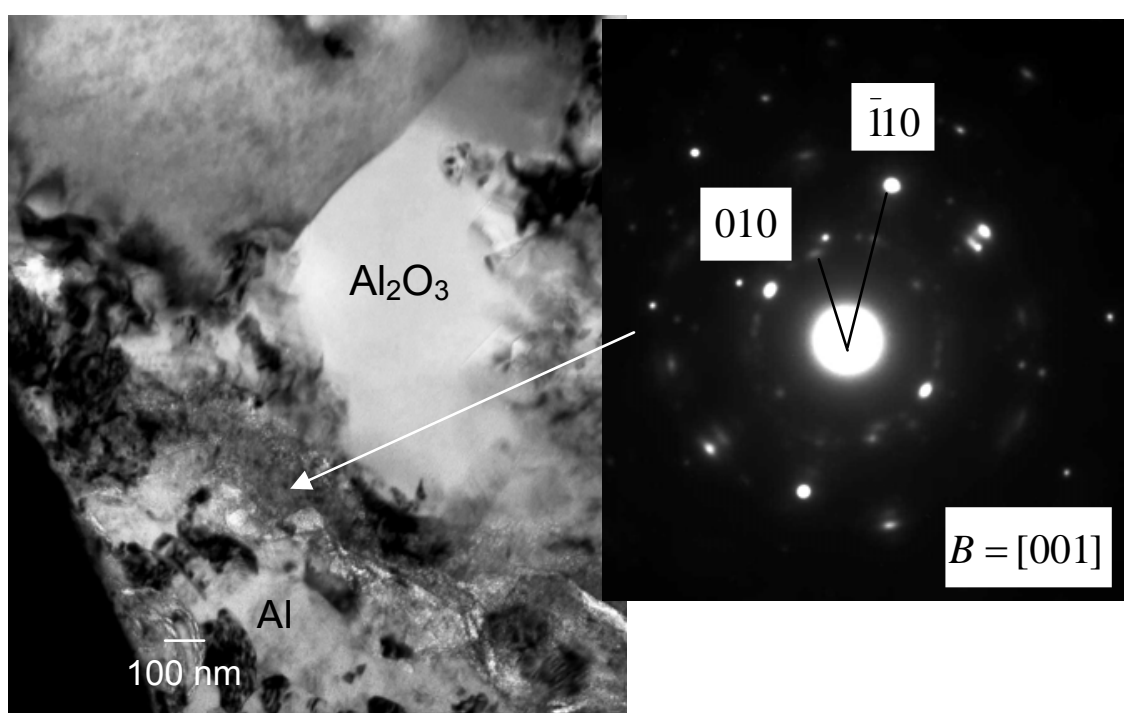

Fig. 6 TEM micrograph and the diffraction patterns of the AIN at the metal-ceramic interface in the composite. 

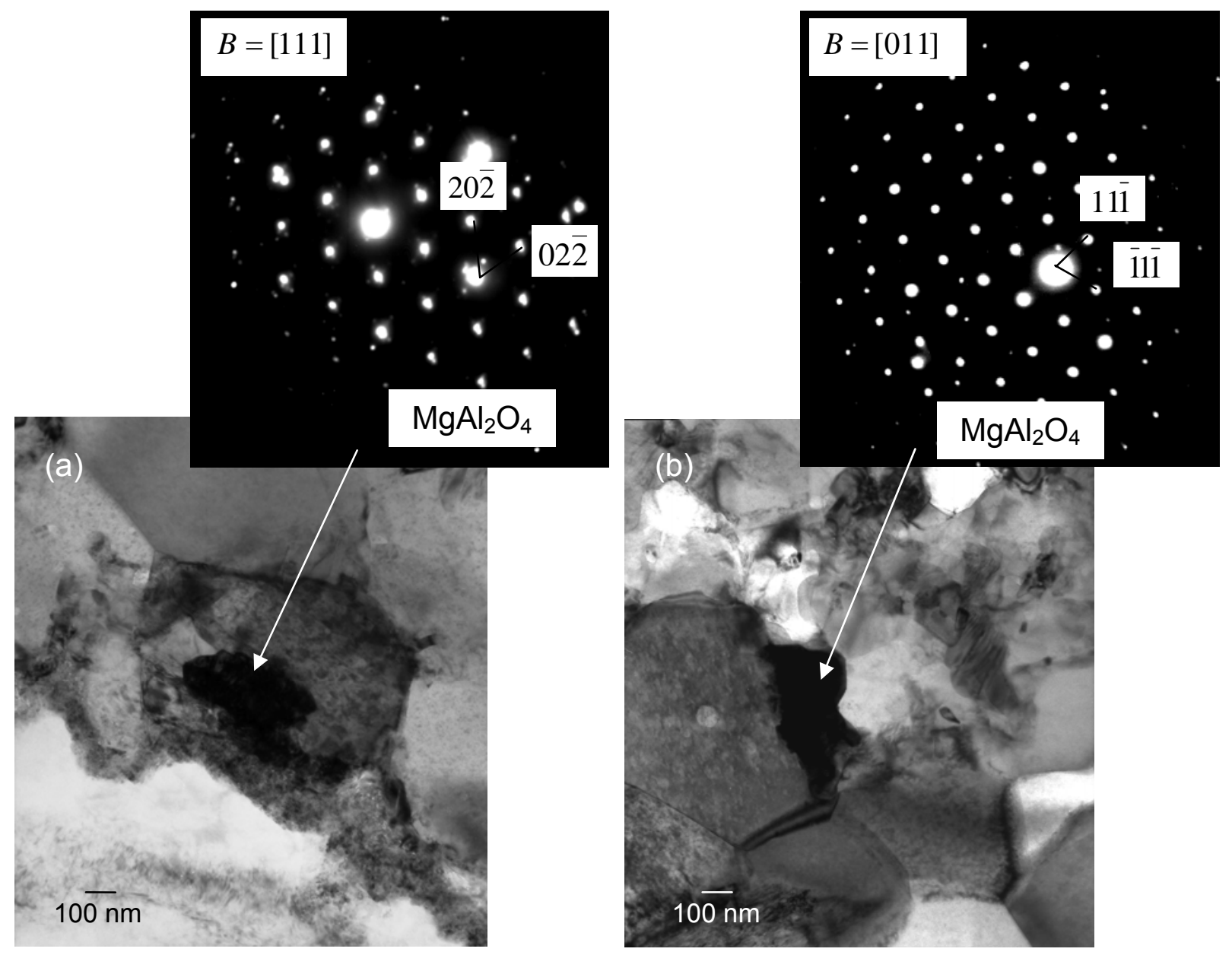

Fig. 7 TEM micrographs and diffraction patterns of the spinel formed (a) at the interface and (b) in the alumina foam strut within the metal-ceramic composites.

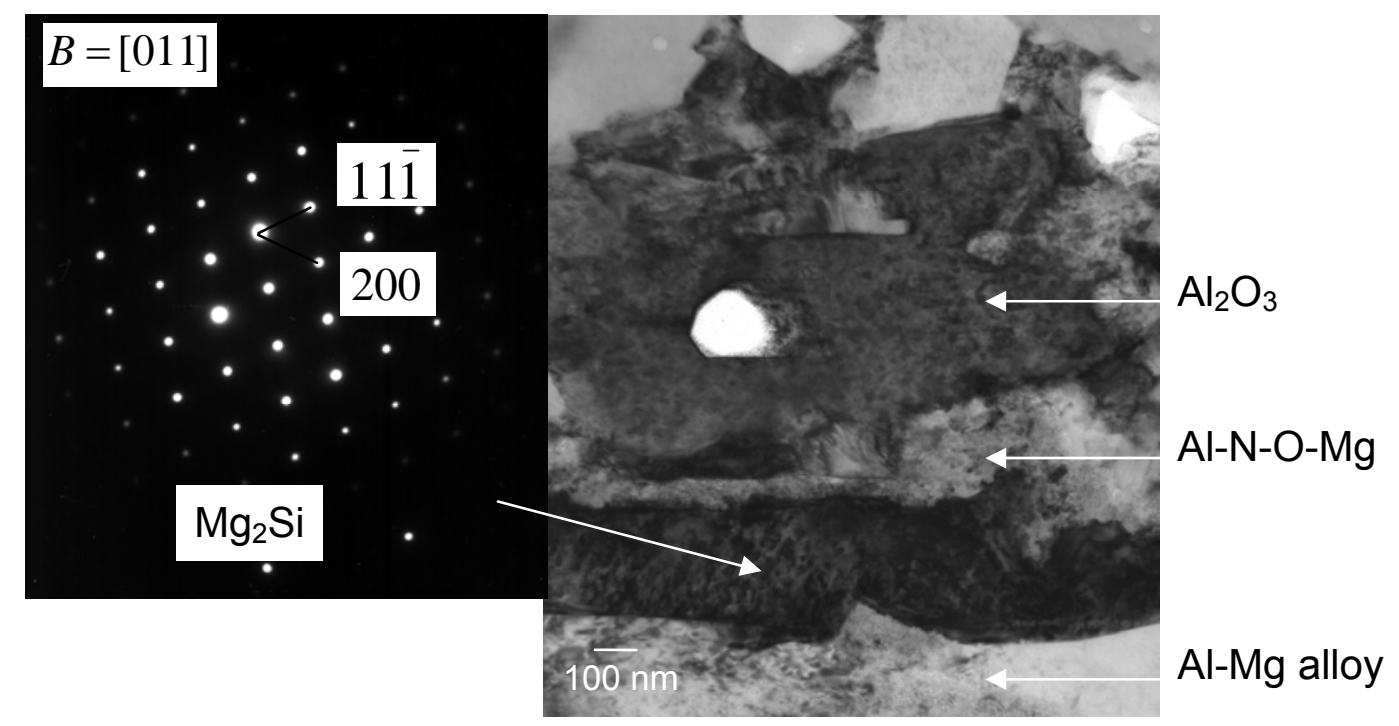

Fig. 8 TEM micrograph and the diffraction pattern of the $\mathrm{Mg}_{2} \mathrm{Si}$ particle detected at the metal-ceramic interface. 

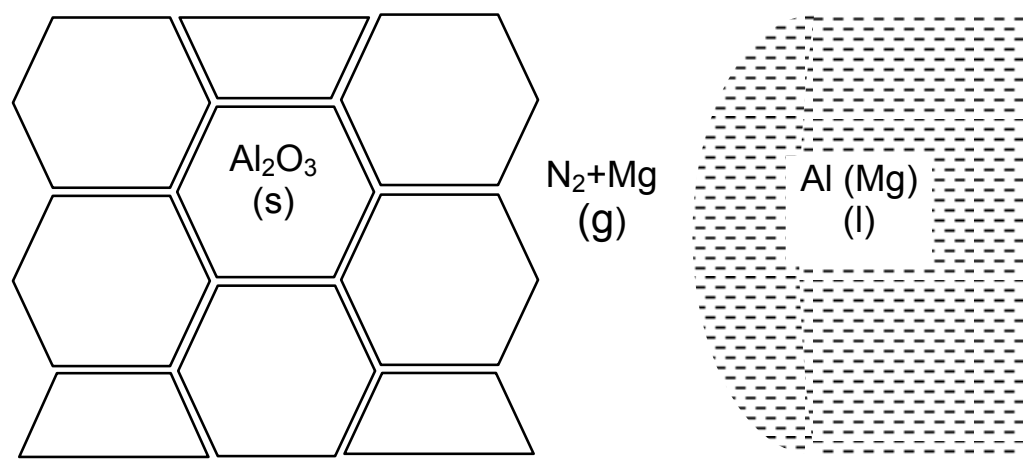

(a)

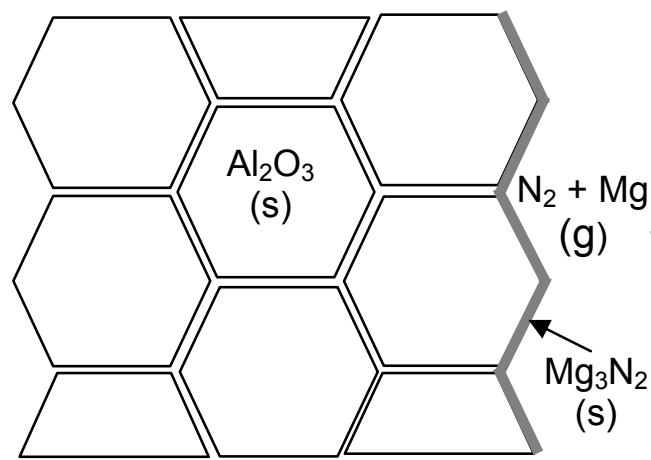

(b)

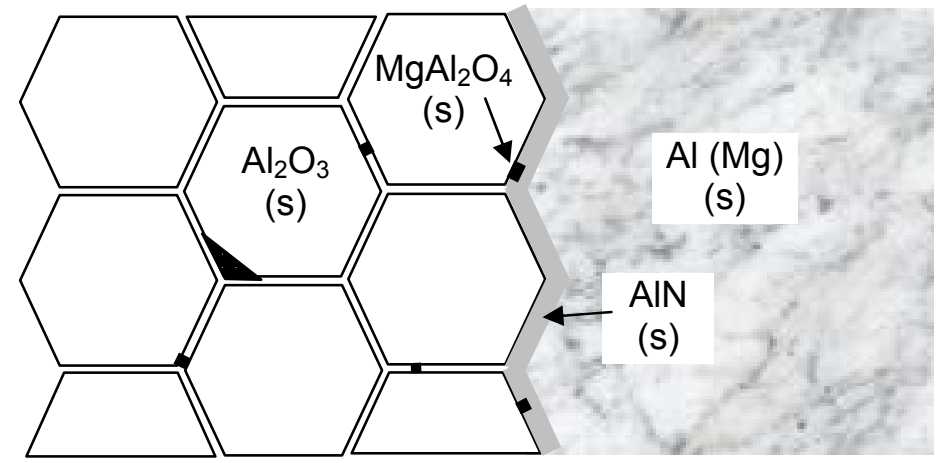

(c)

Fig. 9 Schematics of the reaction assisted infiltration and interfacial development processes: (a) at $915^{\circ} \mathrm{C}, \mathrm{N}_{2}$ was introduced; (b) $\mathrm{Mg}_{3} \mathrm{~N}_{2}$ formed and (c) metalceramic interface formed consisting of a continuous AIN layer and localized $\mathrm{MgAl}_{2} \mathrm{O}_{4}$ 

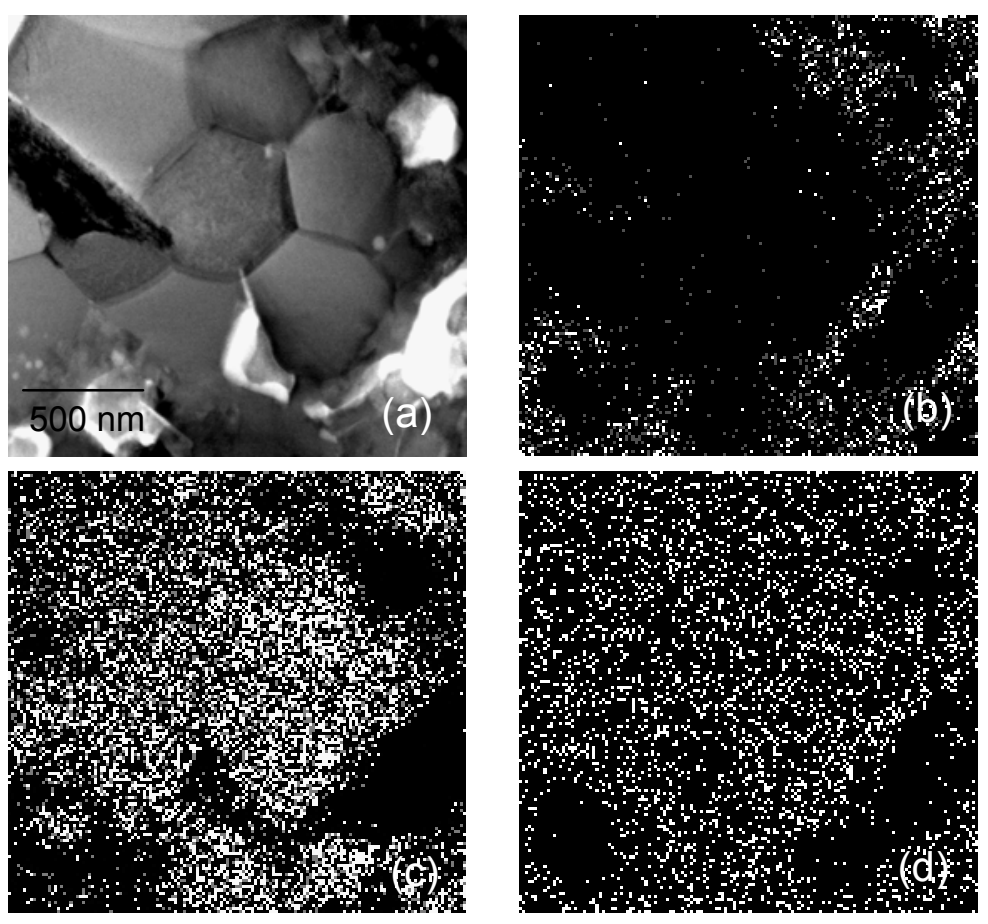

Fig. 10 TEM micrograph of (a) the alumina strut in the infiltrated composite, and the TEM-EDS maps: (b) Mg; (c) Al; (d) O. 
References - shouldn't these be in alphabetical order?

Clarke, D. R. (1992) Interpenetrating Phase Composites, Journal of the American Ceramic Society, 75: 4, 739-759.

Binner, J. G. P., Chang, H., Higginson, R. L. Processing of Ceramic-Metal Interpenetrating Composites, Journal of the European Ceramic Society, Special Issue, in press.

Aghjanian, M. K., Rocazella, M. A., Burke, J. T. et al. (1991) The fabrication of metal matrix composites by a pressureless infiltration technique, Journal of Material Science, 26: 1, 447-454.

Zhong, L. J., Wu, J. B., Qin, J. T. et al. (1989) An investigation on wetting behaviour and interfacial reactions of aluminium - $\alpha$-alumina system, in Interfaces in metal- ceramics composites, Lin, $\mathrm{R} Y$ and Arsenault, $\mathrm{R} J$ (Eds), TMS, Warrendale, PA, USA, 213-225.

Rao, B. S. and Jayaram, V. (2001) Pressureless infiltration of Al-Mg based alloys into $\mathrm{Al}_{2} \mathrm{O}_{3}$ preforms: mechanisms and phenomenology, Acta Materilia, 49, 23732385.

Sercombe, T. B., Schaffer, G. B. (2004) On the role of magnesium and nitrogen in the infiltration of aluminium by aluminium for rapid prototyping applications, Acta Materilia, 52, 3019-3025. 
Saravanan, R. A., Molina, J. M., Narciso, J. et al. (2001) Effect of nitrogen on the surface tension of pure aluminium at high temperatures, Scripta mater, 44, 965970.

Lee, K. B., Kim, Y. S., Kwon, H. (1998) Fabrication of Al-3 wt pct Mg matrix composites reinforced with $\mathrm{Al}_{2} \mathrm{O}_{3}$ and $\mathrm{SiC}$ particulates by the pressureless infiltration technique, Metallurgical and Materials Transactions A, 29A, 3087-3095.

Schiroky, G. H., Miller, D. V., Aghajanian, M. K. et al. (1997) Fabrication of CMCs and MMCs using novel processes, Key Engineering Materials, 127-131, 141-152.

Hou, Q. H., Mutharasan, R., Koczak, M. (1995) Feasibility of aluminium nitride formation in aluminum alloys, Materials Science and Engineering A., 195, 121-129.

Sepulveda, P., Binner, J. G. P. (1999) Processing of cellular ceramics by foaming and in situ polymerization of organic monomers, Journal of the European Ceramic Society, 19: 12, 2059-2066.

Pai, B. C., Ramani, G., Pillai, R. M. et al. (1995) Role of magnesium in cast aluminium alloy matrix composites, Journal of Materials Science, 30, 1903-1911.

Barin, I. (1989) Thermochemical data of pure substances, VCH Verlagsgesellschaft, Weinheim. 